\title{
THE EFFECTS OF CURCUMIN ADMINISTRATION ON EXPRESSION PATTERNS OF VEGF AND COX-2 IN FERTILE ENDOMETRIUM: A RANDOMISED CLINICAL TRIAL
}

\author{
RAJUDDIN RAJUDDIN ${ }^{*}$, BUDI WIWEKO ${ }^{2,3,4}$, LUTFI NUGROHO5
}

1Department of Obstetrics and Gynecology, Faculty of Medicine, Universitas Syiah Kuala, Banda Aceh, Indonesia, ${ }^{2}$ Division of Reproductive Endocrinology and Infertility, Department of Obstetrics and Gynecology, Faculty of Medicine, Universitas Indonesia, Jakarta, Indonesia, ${ }^{3}$ Human Reproductive, Infertility, and Family Planning Research Center, Indonesian Medical Education and Research Institute, Faculty of Medicine, Universitas Indonesia, ${ }^{4}$ Dr. Cipto Mangunkusumo General Hospital Jakarta, ${ }^{5}$ Resident Department of Obstetrics and Gynecology, Faculty of Medicine, Universitas Syiah Kuala, Banda Aceh, Indonesia Email: rajuddin@unsyiah.ac.id

Received: 15 Dec 2018, Revised and Accepted: 10 Mar 2019

\section{ABSTRACT}

Objective: Curcumin (diferuloylmethane) is a a compound isolated from turmeric with biological activities, including antifertility. Curcumin inhibits COX-2 expression in granulosa cells of ovarian follicles and disrupts vascular endothelial growth factor (VEGF) derived angiogenesis in the endometrium, reducing endometrial receptivity. The purpose of this study was to examine the effects of curcumin on COX-2 and VEGF expression in endometrium of fertile women.

Methods: A prospective double-blind placebo-controlled clinical trial was conducted in a group of fertile women with regular menstrual cycles, aged between 20-30 y, married, and with children. Subjects were divided into a group receiving daily 800 mg encapsulated curcumin. Curcumin orally for ten days, starting on the third day of the first menstrual day, and a control group. Endometrial biopsy was performed using a microcuret and immunohistochemistry was used to assess VEGF and COX-2 expression. The results were analysed using an independent sample t-test.

Results: In the curcumin-treated group, VEGF expression was significantly lower than the control group ( $\mathrm{p}<0.05)$, and COX-2 expression was higher but not significantly so $(\mathrm{p}>0.05)$

Conclusion: The curcumin causes VEGF expression in endometrium is lower and negatively affects the growth of endometrial stromal cells.

Keywords: Curcumin, COX-2, VEGF, Antifertility

(C) 2019 The Authors. Published by Innovare Academic Sciences Pvt Ltd. This is an open access article under the CC BY license (http://creativecommons. org/licenses/by/4. 0/) DOI: http://dx.doi.org/10.22159/ijap.2019.v11s6.33581

\section{INTRODUCTION}

Curcumin (diferuloylmethane) is a polyphenol derived from the Curcuma longa plant, commonly called turmeric [1]. Curcumin has antifertility effects and may have applications in female contraception [2, 3], and administration of intravaginal curcumin causes a reversible reduction in fertility [4]. In the endometrium, curcumin acts as a selective COX-2 inhibitor, where the administration of curcumin 100 $\mathrm{mg} / \mathrm{kgBB}$ on the first day of estrus until the fourth day after $\mathrm{LH}$ stimulation decreases COX-2 expression in the luminal epithelium and glandular endometrium, but does not reduce endometrial thickness or cell counts in the luminal epithelium in mice [8]. Meanwhile, vascular endothelial growth factor (VEGF) is a pro-angiogenic factor, produced in glands, endometrial stromal cells, and myometrial smooth muscle, whose expression increases in the late proliferation and endometrial secretory phases, resulting in an increase in endometrial vascularisation $[5-7,14,15]$. Decreasing the thickness of the endometrium will decrease the endometrial receptivity and thus inhibit the implantation process [10], and endometrial thickness can be used as an anatomical parameter to assess endometrial receptivity.

Therefore, we hypothesised that dietary curcumin could lead to a decrease in fertility, as indicated by VEGF and COX-2 expression. We carried out a clinical trial to assess the effect of curcumin on the expression of VEGF and COX-2 in the endometrium at the middle of the menstrual cycle, using microcurets to assess endometrial thickness and Immunihistochemical expression VEGF and COX-2.

\section{MATERIALS AND METHODS}

We carried out a prospective phase III clinical trial study with a randomised double-blind placebo-controlled trial design [11, 12], at the Reproductive Health Clinic/Polyclinic of Central Hospital Dr. Zainoel Abidin, Banda Aceh, and the Rasi Clinic in Banda Aceh, between November 2012 to October 2014. Eighty fertile healthy women with a menstrual cycle of 26-28 d, aged between 20-30y, and who had previously given birth were selected for a clinial trial Women were excluded if they were using contraceptives, receiving hormonal therapy or treatments known to affect the menstrual cycle, or had a history of uterine tumours, unexplained vaginal bleeding, endometrial hyperplasia or endometrial thickness 214 $\mathrm{mm}$ based on transvaginal ultrasound examination, galactorrhea, blood pressure above 160/95 $\mathrm{mmHg}$ or severe hypertension, acute or chronic pelvic infections, or pregnancy. All subjects were monitored for the duration of the trial.

Forty women were randomly assigned to a treatment group was given $800 \mathrm{mg}$ curcumin capsules orally beginning on the third day of menstruation for ten days, while the control group received a placebo. Immunocytochemistry examination of VEGF and COX-2 expression was performed at the Anatomical Pathology Laboratory of the Faculty of Medicine University of Gajah Mada, Yogyakarta, Indonesia. An endometrial biopsy (microcuret) examination was carried out in the middle of the menstrual cycle. Patient in the lithotomy position at the gynecological table. Inserted Sim's speculum into the vagina. Clean the portio with betadin, measure the depth of the uterine cavity with uterine sondase. Give local anesthesia (get $2 \% 4 \mathrm{cc}$ ) into the uterine cavity with a $5 \mathrm{cc}$ syringe. A spoon curette no.1 inserted into the uterine cavity to take endometrial tissue. The tissue was inserted into a glass tube sample containing formalen buffer and the tube was closed tightly, then sent to the UGM Anatomy Pathology Laboratory, Yogyakarta, to produce Histopathological preparations and Immunocy tochemistry l staining. Immunocytochemistry examination for COX-2 examination and VEGF expression. Data were analysed using an independent t-test, where difference were judged to be significant at $\mathrm{p}<0.05$.

\section{RESULTS}

A comparison between curcumin treatment and a control group showed that mean VEGF/100 cell field of view expression. Histopathological preparations and immunocytochemistry staining 
in VEGF expression in the curcumin group were calculate from epithelial surface, vascular endothelium and glandular. This group was significantly lower at $17.18 \pm 12.62$ SD per 100 cells. compared with the control group at $42.78 \pm 32.94$ SD per 100 cells (fig. 1, table I; $\mathrm{p}<0.05$ ). Meanwhile, COX-2/100 cell expression was slightly higher in the curcumin group at $56.68 \pm 26.27 \mathrm{SD}$ per 100 cells compared to $44.43 \pm 31.82$ SD per 100 cells in the control group, but this difference was not significant (fig. 2, table I; $p>0.05$ ). In the group that received curcumin, more cells expressed COX-2 on the epithelial surface, stroma and endometrial glands than controls (fig. 2).

Table 1: VEGF and COX-2 expression calculated from stroma, cytoplasm and endometrial blood vessels in the middle of the menstrual cycle

\begin{tabular}{llllll}
\hline \multirow{2}{*}{ Expression } & \multicolumn{2}{l}{ Curcumin } & \multicolumn{3}{l}{ Control } \\
\cline { 2 - 6 } & $\mathbf{n}$ & $\bar{X} \pm$ SD & $\mathbf{n}$ & $\bar{X} \pm$ SD & $\mathbf{p}$ \\
\hline $\operatorname{VEGF}(\Sigma / 100$ cells $)$ & 40 & $17.18 \pm 12.62$ & 40 & $42.78 \pm 32.94$ & 0.00 \\
COX-2 $(\Sigma / 100$ cells $)$ & 40 & $56.68 \pm 26.27$ & 40 & $44.43 \pm 31.82$ & 0.06 \\
\hline
\end{tabular}

$\Sigma=$ Sum of the immunocytochemistry expression appearance
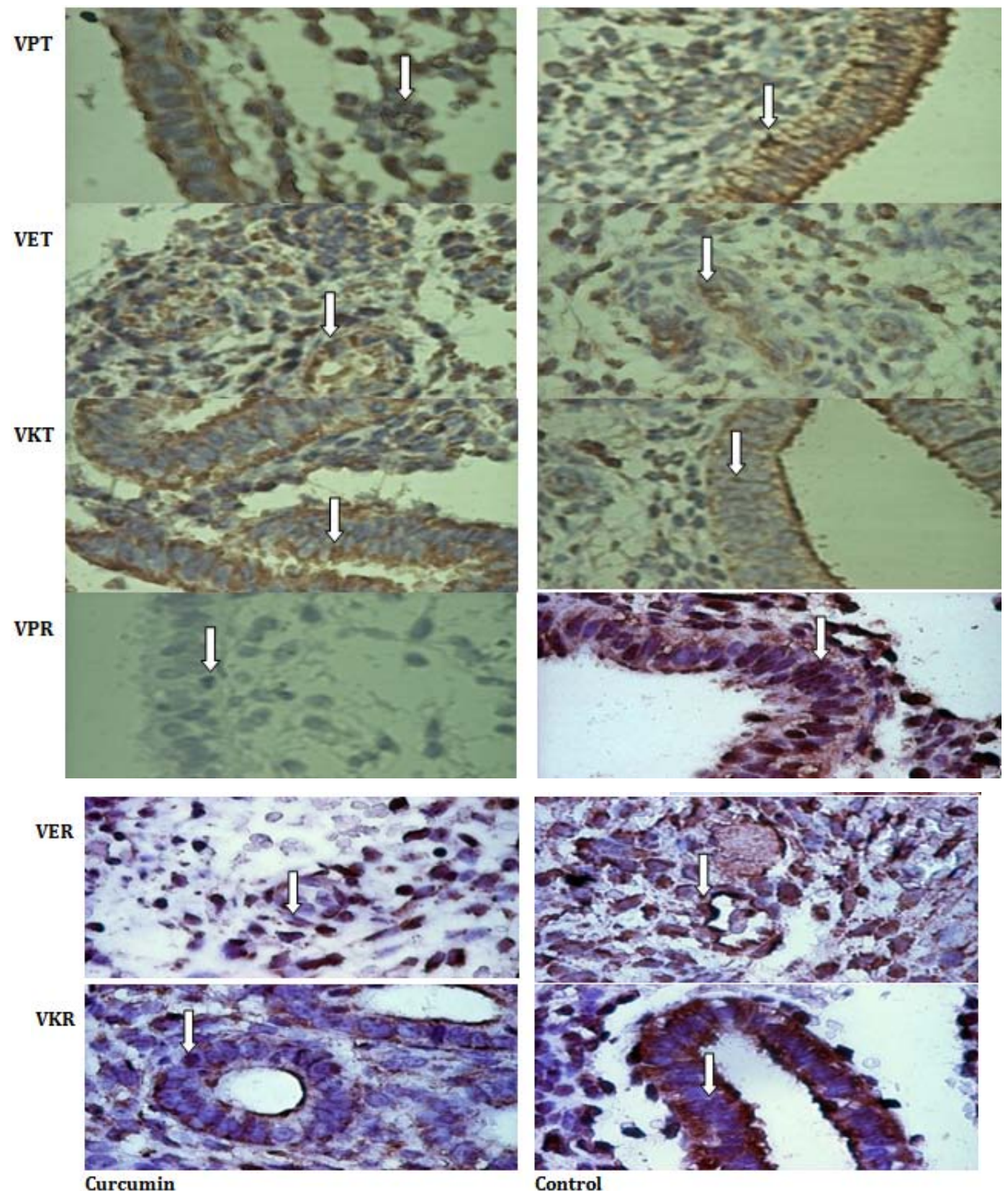

Fig. 1: Immunocytochemistry of VEGF expression on the surface, endothelium and gland after $10 \mathrm{~d}$ of curcumin administration. Endometrial gland cell morphology after Immunocytochemistry staining were characterised by the appearance of purple brown colour from chromogen diaminobenzidine tetrahydrochloride (DAB) in the cytoplasm, and the brown colour in the cytoplasm indicates the presence of VEGF expression. The cell nucleus appears round-oval and the blue/purple colour. Observations using a microscope phase contrast at $400 \times$. VPT = High surface VEGF, VET = Endothelial VEGF High, VKT = High Gland VEGF, VPR = Low surface VEGF, VER = Low Endothelial VEGF, VKR = Low Gland VEGF. The arrows are appearance of Immunocytochemistry of VEGV expression 
CKR

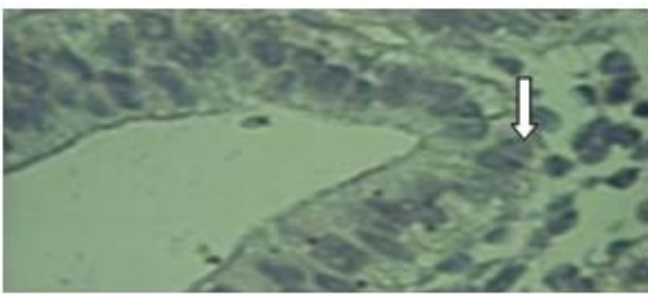

CSR

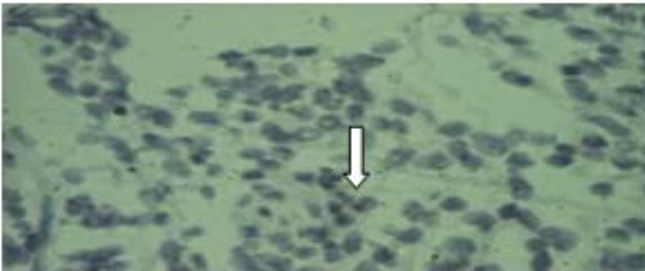

CPR

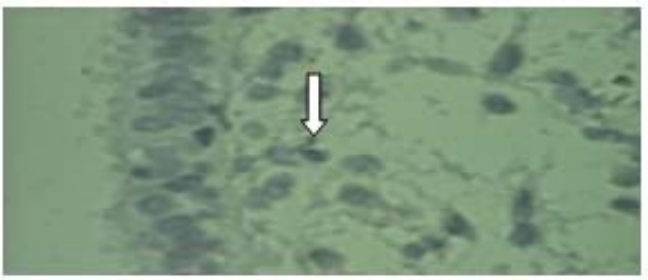

CKT

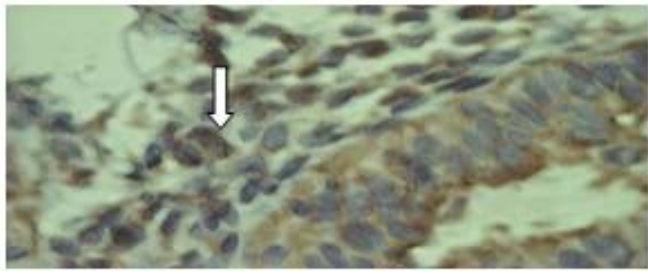

CST

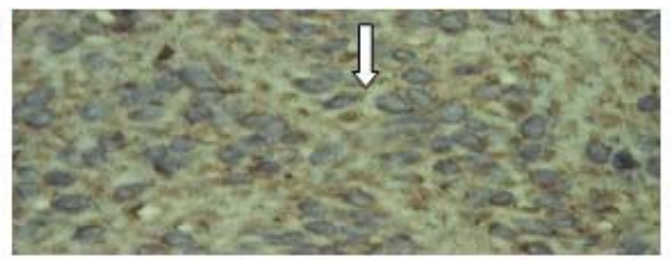

CPT

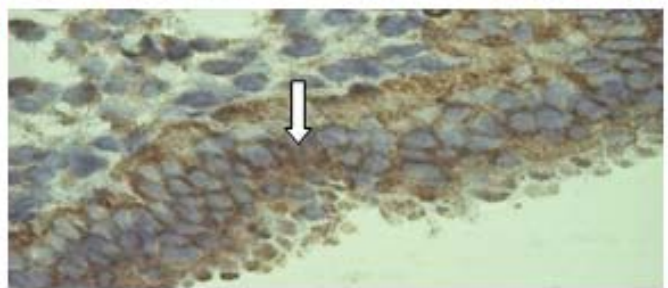

Curcumin
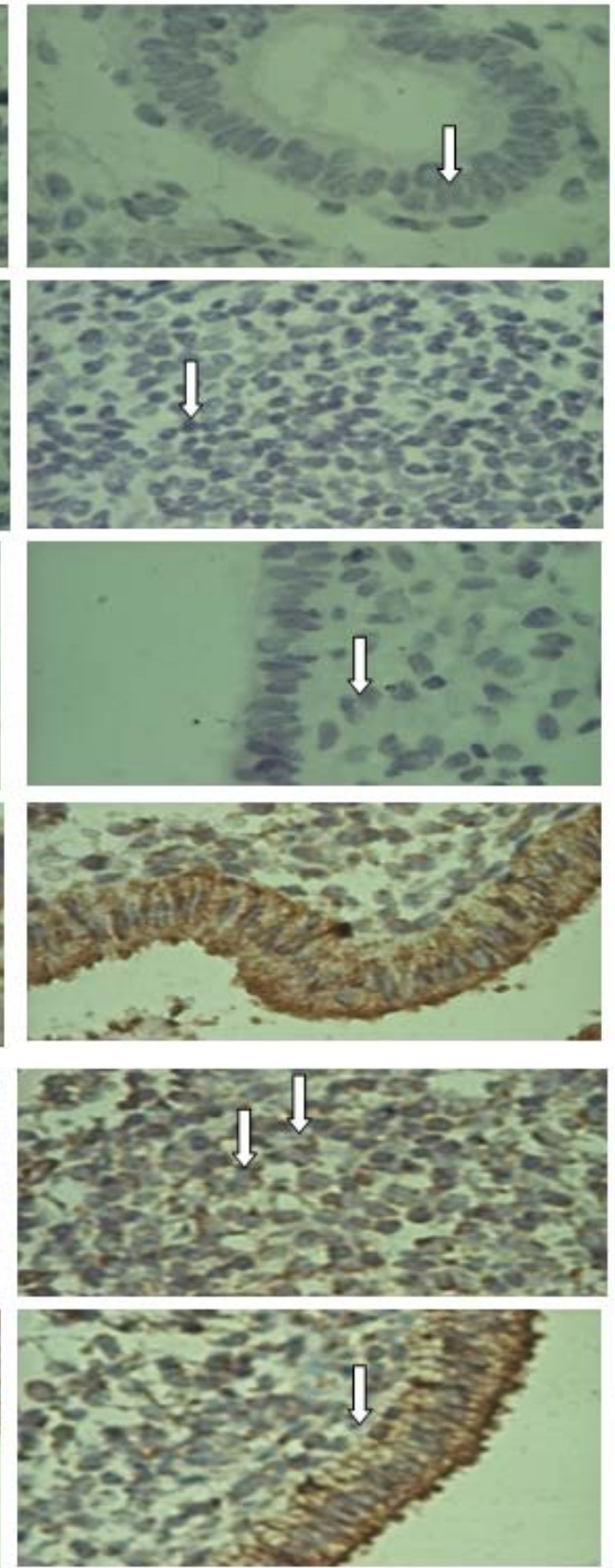

Control

Fig. 2: Immunocytochemistry of COX-2 expression on the surface, endothelium and glands after $10 \mathrm{~d}$ of curcumin administration. The photomicroscopic image of endometrial gland cell morphology after Immunocytochemistry staining is characterised by the appearance of purple-brown colour from chromogen diaminobenzidine tetrahydrochloride (DAB) in the cytoplasm, indicating COX-2 expression. The cell nucleus looks round-oval and blue/purple. Observations were made using phase contrast microscopy with $400 \times$ magnification. Low CKR = COX-2 Gland, Low Stroma CSR = COX-2, Low Surface CPR = COX-2, High CKT = COX-2 Gland, High Stroma CST = COX-2, High Surface CPT = COX-2. The arrows are appearance of Immunocytochemistry of COX-2 expression

\section{DISCUSSION}

\section{The effect of curcumin on VEGF expression}

The amount of VEGF expression was lower in the curcumin group, indicating that curcumin has an antigonadotropic effect. VEGF targets endothelium to induce proliferation and migration for new blood vessels to grow and supply the endometrium, and works as a vasodilator by stimulating the release of prostacyclin and nitric oxide [24]. Curcumin suppresses VEGF secretion depending on the dose and reduces the growth of endometrial stromal cells, and induces apoptosis in endometrial epithelial cells [13]. Wieser et al. found that in an in vitro model of endometriosis, curcumin can decrease VEGF secretion and cell proliferation and induce apoptosis in normal cells and endometrium [13]. In normal endometrium, VEGF expression can be detected in both glandular and stromal epithelium, and expression in glandular cells increases 3-5 fold from the initial proliferation phase to the final secretion phase [16]. VEGF expression is at its highest in the middle of the secretion phase [17]. Macpherson et al. reported that immunoreactive VEGF significantly increased in the endometrial gland during the normal menstrual cycle [18]. In our study, VEGF levels were very low in the curcumin group, indicating that curcumin decreases VEGF expression in the final follicular phase. The results of this study indicate that there was a decrease in VEGF due to administration of curcumin. 


\section{Effect of curcumin on COX-2 expression}

LH and FSH directly activate cAMP in granulosa preovulatory cells via the protein kinas A (PKA) pathway to increase the regulation of COX-2 expression [19, 20]. Similarly, LH can stimulate an increase in COX-2 expression [21]. In this study, the increased COX-2 expression in the curcumin group may indicate that the endometrium and granular cells may be different. Granulosa COX-2 expression cells are increase to the level of prostaglandin in ovarium after 24-36 h hCG administration [22]. Purwanti reported that COX-2 expression was highly increased in experimental animals treated with curcumin after LH stimulation compared to animals given curcumin with placebo[8]. An in vitro study conducted by Adiyanti et al. found that administration of curcumin at $100 \mathrm{mg} / \mathrm{KgBW}$ yielded a significant difference in increasing VEGF expression compared to a group treated with indomethacin, a non-selective COX inhibitor [9]. Meanwhile, curcumin is a selective COX-2 inhibitor, which stimulates apoptosis and angiogenesis inhibitors [8]. The presence of curcumin inhibitors such as COX-2 inhibitor during the adenylate cyclase and phospholipase pathway will reduce COX-2 expression [8].

Adenylate cyclase catalyses the formation of cAMP from ATP. cAMP stimulates the release of $\mathrm{Ca}^{2+}$ from the endoplasmic reticulum and activates PKA. The released $\mathrm{Ca}^{2+}$ binds to calmodulin and affects the activity of the COX-2 enzyme. Through the phospholipase pathway, active phospholipase will cause degradation of PIP2 (Phatidylinositol bisphosphate) into IP3 (inositol 1,4,5 triphosphat), which stimulates the release of $\mathrm{Ca}^{2+}$ ions that bind to calmodulin, and DAG (Diacylglyserol), which activates protein kinase c (PKC). PKC and $\mathrm{Ca}^{2+}$ binding with calmodulin will increase COX-2 [21]. Curcumin inhibits COX-2 expression in the follicular granulosa cells in the ovary, with the inhibition taking place prior to cAMP production [23]. Although our study indicated a moderate increase in COX-2 under curcumin treatment, this was not significant, in contrast to our hypothesis.

\section{CONCLUSION}

We found that curcumin reduces VEGF expression in the endometrium, but does not affect COX-2 expression. This study indicate that Curcumin is promising in acting as an antifertility or contraceptive agent. In the future, further research needs to be done, involving multicentres and large sample size with the aim of fertility regulation and antifertility treatment. This will strengthen the scientific basis for its use as fertility regulating drugs.

\section{ACKNOWLEDGEMENT}

This article was presented at The $3^{\text {rd }}$ International Conference and Exhibition on Indonesian Medical Education and Research Institute (ICE on IMERI 2018), Faculty of Medicine, Universitas Indonesia, Jakarta, Indonesia. We thank Prof. Dr. Sri Kadarsih Soejono, Prof. dr. Mohammad Hakimi, and Dr. Indwiani Astuti, who provided direction, guidance and discussion; Prof. Dr. Suwijiyo Pramono; Dr. Hariyadi for examining immunohistology slides and assessment of VEGF and COX-2 expressions; Mr. Yunadir, Mr. Sumantri, and Agustin for technical assistance; Ners, Helmi Hartati, and S. Kep, who helped in patient preparation for performing microcuret tissue sampling at the Tara Clinic; and colleagues in the Obstetrics and Gynecology department at the University of Syiah Kuala/Central Hospital Dr. Zainoel Abidin, Banda Aceh, Indonesia. We also thank the $3^{\text {rd }}$ ICE on IMERI Committee who had supported the peer review and manuscript preparation before submitting to the journal.

\section{AUTHORS CONTRIBUTIONS}

All the author have contributed equally

\section{CONFLICT OF INTERESTS}

There are no conflicts of interest to declare

\section{REFERENCES}

1. Aggarwal BB, Kumar A, Bharti AC. Anticancer potential of curcumin: preclinical and clinical studies. Anticancer Res 2003;23:363-98.
2. Chattopadhay I, Kausnik B, Bandyopadhyay U, Banerjee RK. Turmeric and curcumin: biological actions and medicinal applications. Curr Sci 2004;87:44-53.

3. Rithaporn T, Monga M, Rajasekaran M. Curcumin: a potential vaginal contraceptive. Contraception 2003;68:219-23.

4. Naz RK. Can curcumin provide an ideal contraceptive? Mol Reprod Dev 2011;78:116-23.

5. Kressin P, Wolber EM, Wodrich H, Malik AM, Buchweitz O, Diedrich K, et al. Vascular endothelial growth factor mRNA in eutopic and ectopic endometrium. Fertil Steril 2001;76:1220-4.

6. Smith SK. Angigenesis, vascular endothelial growth factor and the endometrium. Human Reproduction Update 1998;4:509-19.

7. Felemban A, Sammour A, Tulandi T. Serum vascular endothelial growth factor as a possible marker for early ectopic pregnancy. Hum Reprod 2002;17:490-2.

8. Purwanti E. Ekspresi cyclooxygenase-2 (COX-2), ketebalan endometrium dan jumlah sel epitel luminal uterus akibat pemberian kurkumin pada rattus norvegicus strain sprague dawley setelah mendapat stimulasi luteinizing hormone. Thesis, Universitas Gadjah Mada, Yogyakarta, Indonesia; 2009.

9. Adiyanti SS. Perubahan reseptivitas endometrium rattus norvegicuc fase estrus akibat pemberian kurkumin. Tesis, Universitas Gadjah Mada, Yogyakarta, Indonesia; 2006.

10. Elnashar, Aboul-Enein. Endometrial reseptivity. Middle East Fertility Society J 2004;9:10-24.

11. Altman DG, Schulz KF, Moher D, Egger M, Davidoff F, Elbourne $\mathrm{D}$, et al. The revised CONSORT statement for reporting randomized trials: explanation and elaboration. Ann Intern Med 2001;134:663-94.

12. Schulz KF, Altman DG, Moher D, Grup C. Research methods and reporting CONSORT 2010 statement: updated guidelines for reporting parallel group randomised trials. Br Med J 2010;304:698702.

13. Wieser F, Yu J, Park J, Sidell N, Taylor RN. Curcumin suppresses angiogenesis, cell proliferation and induces apoptosis in an in vitro model of endometriosis. Fertility Steril 2007;88:204-S205.

14. Felemban A, Sammour A, Tulandi T. Serum vascular endothelial growth factor as a possible marker for early ectopic pregnancy. Hum Reprod 2002;17:490-2.

15. Charnock Jones DS, Sharkey AM, Rajput Williams, Burch D, Schofield JP, Fountain SA, et al. Identification and localization of alternately spliced mRNAs for vascular endothelial growth factor in human uterus and estrogen regulation in endometrial carcinoma cell lines. Biol Repro 1993;48:1120-8

16. Saito M, Sato $Y$, Watanabe J, Kuramato H, Kaba S, Fukuda T. Angiogenic factors in normal endometrium and endometrial adenocarcinoma. Pathol Intern 2007;57:140-7

17. Sugino N, Kashida S, Karube Harada A, Takiguchi S, Kato H. Expression of vascular endothelial growth factor (VEGF) and its receptors in human endometrium throughout the menstrual cycle and in early pregnanc. Reproduction 2002;123:379-87.

18. Macpherson AM, Archer DF, Leslie S, Charnock Jones DS, Makkink WK, Smith SK. The effect of etonogestrel on VEGF, oestrogen and progesterone receptor immunoreactivity and endothelial cell number in human endometrium. Hum Reprod 1999;14:3080-7.

19. Wong WY, DeWitt DL, Smith WL, Richards JS. Rapid induction of prostaglandin enderoperoxide synthase in rat periovulatory follicles by luitenizing hormone and camp is blocked by inhibition of transcription and translation. Mol Endocrinol 1989;3:1714-23.

20. Wong WY, Richards JS. Induction of prostaglandin H synthase in rat preovulatory follicles by gonadotropin releasing hormon. Endocrinol 1992;130:3512-21.

21. Shemesh M. Actions of gonadotrophins on the uterus. J Repro Fertil 2001;121:835-42.

22. Sirois J, Sayasith K, Brown KA, Stock AE, Bouchard N, Dore M. Cyclooxygenase- 2 and its role in ovulation; a 2004 account. Hum Reprod Update 2004;10:373-85.

23. Puspita D. Ekspresi cyclooxygenase-2 (COX-2) di sel granulosa folikel ovarium akibat pemberian kurkumin dengan dan tanpa penambahan teofilin setelah stimulasi LH. Thesis, Universitas Gadjah Mada, Yogyakarta, Indonesia; 2011.

24. Smith SK. Angigenesis, vascular endothelial growth factor and the endometrium, Human Reproduction Update; 1998. p. 509-19. 